\title{
The Development of Interactive Multimedia with Drill and Practice Model on Multimedia Ii (Two Dimention Animation) Course in Politeknik Ganesha Guru
}

\author{
Kadek Agus Hendra Pujawan ${ }^{1}$
}

1,Politeknik Ganesha Guru, Denpasar, Bali

A R T I C L E I N F O

Article history:

Received 18

Desember 2017

Received in revised

form

8 Januari 2018

Accepted 14

Februari 2018

Available online 20

Februari 2018

Keywords:

Interactive Multimedia,

Drill Model, Dick and

Carey

\begin{abstract}
A B S T R A C T
This study aims (1) To create interactive multimedia design with drill and practice model at Multimedia II (animation 2 dimension) course, (2) To know the feasibility of interactive multimedia with drill and practice model at Multimedia II (animation 2 dimension) course. The type of study used was Research and Development by using development model of Dick \& Carey. This study involved the first grade students of Informatika Management program at Politeknik Ganesha Guru. Based on the result of data analysis which is derived from the content feasibility aspect performed by the content expert showed that the product was acceptable with SAP of Multimedia II (animation 2 dimension) course. In the tests which were performed by the media expert obtained $85 \%$ calculation results are in good qualification. In the tests which were done by the design of the learning expert obtained $88 \%$ calculation results are in good qualification. The user/lectures gave good response. Field trials that were conducted obtained a calculation of $89 \%$ are in good qualification.
\end{abstract}

\section{Introduction}

Improving the quality of education in universities is determined by lecturers, curriculum, facilities and adequate infrastructure and all that takes a learning process. . In this regard, Rooidjakkers (1993) states that teaching is an attempt to pass on the knowledge to others. Teaching is all efforts made by the lecturer in the form of deliberate to convey knowledge and views as well as providing the possibility for learners to enable the learning process according to the purpose. Furthermore, Gagné, et al (1992) says that learning is an activity that can make students learn and easy to know what was delivered. As a learning resource, a lecturer must have the ability to interact with learners well. The development of science and technology influence and bring out the change in the world of education (Wicaksono, 2016). Besides, lecturers can also be a facilitator. Politeknik Ganesha Guru is a universitiy that apply multimedia in the learning process, but in reality it has not been fully implemented. Based on the results of interviews to the lecturers of multimedia II courses, the learning is still using the power point media in the presentation of material and practicum. The difficulty is found when students tend to be less active in the multimedia learning process II, besides the time given for multimedia II course is 3 SKS, while the time to practicum to do an animation takes a long time, so that the task given is not completed well. From that problem, it is needed an innovation in the learning process that is interactive multimedia.

Mayer (2005) says that achievement learning with interactive multimedia more effective. This is because the animation in interactive multimedia can present things that are not visible and difficult to imagine (Wiyono, 2013). Moreno (1998) with interactive multimedia research shows that study with interactive multimedia better than the other media. One of the causes of the importance of using media in 
teaching and learning is actually caused by the fact that all human beings are different (Sutijati, 2010). To achieve this, of course, cannot be separated from the use of instructional media is a tool to convey message. Hence concern for each lecturer is how a teacher is able to select and use the media as well as the characteristics of the material, the nature and characteristics of science as well as the characteristics of students Problems often arise regarding the use of instructional media and the availability of using media. Media bank are still less that the teachers use the media to a minimum. The second problem is the use of the media. Print media and media power point is the media most frequently used by teachers, because it is easy to develop and searched from various sources. However, most of the media used is highly dependent on verbal symbols (words) that are very abstract, so it requires a very high abstraction abilities of learners, it is this which can complicate the student. As participants in the use of this media, creativity and judgment required teacher. In fact, instructional mature than is often seen, many teachers use instructional media "roughing" without consideration learning (Instructional consideration). Interactive learning media include a variety of media are integrated into one. Each component of the media can stimulate one or more of the human senses. Ahmizar (2008) explains that "the more senses involved in the learning process, the learning process will be more effective". Explicitly, this theory suggests the use of more than one human's sense. Research by effendi (2013) about development instructional model base interactive multimedia for instructional Mekanika explained that learning achievement more effective than the other media. The same as Rini research (2011) explained that learning achievement with multimedia better than the other media. Supposedly an interactive multimedia system can provide learning materials that the difficulty level according to the user's ability and learning how to present the material in accordance with intelligence users (Dinafitri, 2016). In other words, interactive multimedia system should be able to adapt zoom to a wide variety of user characteristics, so as to have a high learning effectiveness including its intelligence characteristics (Wiyono, 2012).

The research that was conducted by Mochamad Miswar Hadibin, Bambang Eka Purnama and Gesang Kritianto (2012) mentioned that learning by using interactive multimedia-based on learning media increase the interest and response of students in receiving the subject matter. This is in common with the results of development that the author did. This is in line with the results of research Ling Wang (2008), his research developed learning program software based on multimedia. The results show that the programs developed are effective in terms of student learning outcomes and provide recommendations to educators to consider adopting such programs in their learning. Lee and Tseng (2008) in his research stated that, the use of digital content instruments in learning resulted in significant differences in student achievement, when compared with traditional learning.

Multimedia developed at this time tends to only display text and images, so that the visual displayed is not able to explain the material presented. Moreno (1998) with interactive multimedia research shows that study with interactive multimedia better than the other media. The direction of multimedia development today is a two-way communication, meaning it has the ability to accommodate user responses, and perform various activities that can also be responded back by a multimedia program with a feedback. This level of interactivity is a benchmark in assessing the quality of interactive multimedia programs. Interactive multimedia created must be able to fullfil some of the criteria desired by learners such as the characteristics of learners and should be able to increase the motivation of learners, especially students.

Interactive multimedia which is developed byusing drill and practice model is intended to train users to have skills or to strengthen their control over a concept. This program also provides a series of questions that are usually displayed at random, so that whenever it is used, the questions that appear will always be different, or at least in different combinations. Drill and practice is essentially a learning strategy that aims to provide a more concrete learning experience through the provision of exercise questions aimed at testing students' performance skills through the speed of completing the training questions provided (Erik, 2009: 18).

The advantage of using interactive multimedia drill and practice model is to encourage the feedback of learners, providing feedback responses that can improve the learner activity in the classroom. The importances of the development of interactive multimedia are to make the learning process more interesting, more interactive, the amount of teaching time becomes more effective, the quality of learning can be improved, and the teaching and learning process can be done anywhere and anytime, and also student attitudes in learning can be improved.

\section{Method}


The research method used is Dick \& Carey's development research model. Dick \& Carey model is used for the development of interactive multimedia teaching materials with drill model. Steps on the Dick and Carey model show a very clear, uninterrupted relationship between one step and another. In other words, the system contained in Dick and Carey is very concise, but the content is solid and clear from one sequence to the next (Dadang Supriatna, 2009). The steps of development consist of five steps, namely (1) Determining the subjects that become the object of development; (2) Analyze everything needed in draft development such as objective analysis and subject characteristics, analysis of learning resources and analysis of learners' characteristics; (3) The process of media development; (4) Production; (5) Expert review and product trials. Trials include expert content responses, media experts, design experts, user/lecturer trials, and field trials related to interactive multimedia feasibility of student responses. expert will be given a questionnaire with criteria according to the expertise of such experts such as 31 and revisions. Data were analyzed by using descriptive statistical technique. According Sugiyono (2012) descriptive statistics are statistics used to analyze data by way of describing or despicting the data that has been collected as it is without intending to make conclusions that apply to the public or generalization. Furthermore, to calculate the percentage of all subjects used the following formula.

\section{$\mathrm{P}=\sum($ Answer $X$ highest weight $) \quad X 100 \%$ NX highest weight}

(Arikunto, 2008:35)

Where:

$P$ : Percentage

E : total

$\mathrm{n}$ : total of all quessioneer items

To be able to give meaning in decision making it is used the determination by using the conversion table of achievement level with Scale 5 as presented in table 1 . Here is the conversion table of achievement level with scale 5 .

Tabel 1. Conversion of Achievement Level with Scale 5.

\begin{tabular}{lll}
\hline Achievement Level (\%) & Qualification & Explanation \\
\hline $90-100$ & Very Good & Revisions are not required \\
$75-89$ & Good & Revisions are not required \\
$65-74$ & Enough & Revised \\
$55-64$ & Deficient & Revised \\
$0-54$ & Very Deficient & Revised \\
\hline
\end{tabular}

\section{Result}

The result of this development research is interactive multimedia product of drill and practice model on multimedia II learning (2 Dimension animations). The product is developed by using the stages of the Dick and Carey model development procedure that is (1) Determining the course that become the object of development; (2) Analyze everything needed in development draft such as objective analysis and subject characteristics, analysis of learning resources and analysis of learners' characteristics; (3) The process of media development; (4) Production; (5) Expert review and trial. In the process of determining the course that become the object of development and Analyzing everything needed in the development of the draft such as the analysis of objectives and characteristics of subjects, analysis of learning resources to analysis of the characteristics of learners aims to obtain preliminary data before developing interactive multimedia products, the data is analyzed to find a way out of the problems found, then design the storyboard. Storyboard is a description of the scene, visual form of design, audio, duration, description and narration for sound will be made on the storyboard design. The results of the storyboard design will become the reference in making the display at the implementation stage (Binanto, 2010). One of the 
advantages of making designs using storyboards is that users have a wider scope for managing the design flow so as to have stronger effects or interests. In addition, with the visualization, a group of people or organizations of multimedia developers able to exchange ideas together, put the idea on the storyboard and rearrange the storyboard (Reinald, 2011). After the storyboard was prepared subsequently, it create interactive multimedia until production in the form of CD / DVD.

Expert reviews and trials show that interactive multimedia is appropriate to be used in the Politeknik Ganesha Guru at Informatics Management Study Program. The inputs from the stage of expert review and trial that is from the media expert states that the use of language in interactive multimedia must be consistent. The use of clear words and languages in the text elements used in interactive multimedia, the text can provide many meanings to express the meaning, so it is very important in delivering the information to present an interesting application. Kridalaksana (2011:238) in his Linguistic Dictionary states that the text is (1) the most complete abstract language unit, (2) the sequence of sentences, words and so on which in the form of speech, (3) the speech produced in human interaction. Judging from the three meanings of texts put forward in the Linguistic Dictionary it can be said thi 32 text is a unit of language that can be written language and can also be spoken language which is proc...... from interaction or human communication. So with the use of clearly words and language can increase interest in reading interactive multimedia users.

The design expert mentions that there are some inappropriate editorials on the sub-exercise questions, in this case it made a revision by changing the editorial and refine the exercise of the questions made so that in accordance with the topic of SAP multimedia 2 course (2 Dimensional animation), then held an individual test involving 3 students, after being declared valid proceed to small group trial involving 8 students and found some revisions such as the text color in the help button is less clear because the color is too close to the background, in this case it made improvements that change the color to look clear.

The results of the discussion in field trials stated that interactive multimedia products are worth to be used because of the drill and practice-based interactive multimedia: (1) assisting students in understanding abstract and microscopic concepts, simplifying complex calculations, and accelerating the continuity of the teaching and learning process. Complete presentation of information or skills, and systematically design of the information scope and skills according to the level of capability and time allocation; (2) assist students in activating psychological functions in themselves, among others, in focusing attention and maintaining attention, maintaining mental balance, and encouraging independent learning. Another function of interactive multimedia in the world of education is as software learning, which provides facilities to students to learn a material. Multimedia has the following features: (1) interactive by providing ease of feedback (2) freedom of determining learning topics (3) systematic control in learning process (Munir, 2008).

Leow's (2014) research results revealed that interactive multimedia supports the active and flexible learning. Interactive multimedia also improves the quality of student learning, motivates students in the learning process, and focuses the learning on the students.

\section{Conclusions and Recommendations}

Interactive multimedia with model of drill and practice on multimedia II learning developed in this study is categorized as valid. The validation process is carried out through individual pilot activities, small group trials and field trials to search for student responses. Validated focus includes design, content, and media.

Media expert assessment with $85 \%$ calculation result is in good qualification. Design expert assessment with $88 \%$ calculation result is in good qualification, so interactive multimedia drill model does not need to be revised. Based on the result of expert assessment, the content expert asssessment can be seen the contents of learning materials in interactive multimedia is in accordance with SAP multimedia II course (2 dimensional animation) and does not need to be revised. User/lecturer assessment is the material in interactive multimedia is in accordance with the criteria of an interactive multimedia in multimedia II course (2 dimensional animation) which will be used in the second semester Informatics Management Study Program, Student response result of calculation of $89 \%$ if it converted with conversion table the level of achievement with the scale of 5 results calculations are in excellent qualifications, so the interactive multimedia with drill model does not need to be revised.

Researchers realize that the development of interactive multimedia with drill and practice model still has many shortcomings. Viewed in terms of material substance, appearance, interactivity and many other shortcomings. Therefore, the next researcher can present a more complete lesson material, and 
making multimedia to be more interactive and lift the look nuanced Local Culture. Development of interactive multimedia with drill and practice model in trials in other universities. In line with technological developments, researchers can further apply with android based.

\section{References}

Ahmizar, F. (2008), Mengoptimalkan Multimedia Sebagai Sarana Mencerdaskan Bangsa. http://www. Fahmi.az@hotmail.cim. Diunduh tanggal 20 Oktober 2017.

Arikunto, S. 2008. Dasar-dasar evaluasi. Jakarta: Bumi aksara.

Binanto, Iwan. 2010. Multimedia Digital Dasar Teori + Pengembangannya. Yogyakarta : Andi.

Dinafitri, Helsy, Ketang Wiyono, \& Abidin Pasaribu. 2016. Development Of Interactive Multimedia Based Multiple Intelligence On The Sound Waves For Students Of Class XII Senior High School. Proceedings of the 2nd SULE - IC 2016, FKIP, Unsri, Palembang.

Erik, M. A. (2009). Efektivitas Peningkatan Hasil Belajar Dengan Menggunakan Multimedia Interaktif Model Drill And Practice Dalam Pembelajaran TIK. Skripsi Jurusan Pendidikan Ilmu Komputer UPI: Tidak diterbitkan

Lee, Szu Hsin;Tseng, Hui Ching, 2008. "Investigation of Technology Integrated Instruction in Art Education: A Case Study of Exploring Learning Achievement" Journal of Educational Multimedia 33 Hypermedia, 17 (3), pg. 337-361.

Leow, F.T. 2014. Interactive Multimedia Learning: Inovating Classroom Education in a Malaysian University. The Turkish Online Journal of Education Technology, (Online), 13 (2): 99-110, (http://files.eric.ed.gov/fulltext/EJ1022913.pdf) diakses 5 November 2014.

Wang, Ling, 2008. "Developing and Evaluating an Interactive Multimedia Instructional Tool: Learning Outcomes and User Experiences of Optometry Students", Journal of Educational Multimedia and Hypermedia,17(1) pg. 43-57.

Mayer. R.E. (2005), The Cambridge Handbook of Multimedia Learning. USA, Cambridge University Press.

Mochamad Miswar Hadibin, Bambang Eka Purnama, Gesang Kritianto, 2012.“Pembangunan Media Pembelajaran Teknik Komputer Jaringan Kelas X Semster Ganjil Pada Sekolah Menengah Kejuruan Taruna Bangsa Pati Berbasis Multimedia Interaktif", Jurnal Speed 13, Vol 9 No 2:432-437.

Moreno, R., \& Mayer, R.E. (1998), A Learner-Centered Approach To Multimedia Explanations: Deriving Instructional Design Principles From Cognitive Theory. Interactive Multimedia Electronic Journal of Computer-Enhanced Learning.. (online). (http://imej.wfu.edu/articles/2000/2/05/ index.asp J.Diakses 16 Oktober 2017.

Munir. (2008). Kurikulum Berbasis Teknologi Informasi dan Komunikasi. Bandung: ALFABETA

Reinald. 2011. Storyboard. http://revivalentine.com di akses rabu, 18 Mei 2011.

Rini. (2011), Pengaruh Pembelajaran Bebasis Multimedia dan Gaya Kognitif Terhadap Kemampuan Pemecahan Masalah Matematika Siswa SMP Negeri Lubuk Pakam. Laporan Hasil Penelitian Tesis

Rooijakkers, Ad. (1993), Mengajar Dengan Sukses: Petunjuk Untuk Merencanakan dan menyampaikan Pengajaran. Jakarta, Gramedia.

Sugiyono. 2012. Statistika Untuk Penelitian. Bandung: ALFABETA. 
Supriatna, D. 2009. Konsep Dasar Desain pembelajaran. Jakarta: Pusat Pengembangan dan Pemberdayaan Pendidik dan Tenaga Kependidikan.

Sutijati, Rosemarie. 2010. Kemutlakan Penggunaan Multimedia sebagai Upaya Penciptaan Pembelajaran Interaktif. Jurnal Ilmiah Maranatha. 17 (2): 114. Universitas Kristen Maranatha Bandung

Wicaksono, Satriyo. 2016. The Development Of Interactive Multimedia Based Learning Using Macromedia Flash 8 In Accounting Course. Journal of Accounting and Business Education,Volume 1 Nomor 1.

Wiyono, K., dkk. (2009). "Model Pembelajaran Multimedia Interaktif Relativitas Khusus untuk Meningkatkan Keterampilan Generik Sains Peserta didik SMA".Jurnal Pendidikan IPA 3(1), 21-29.

Wiyono, K. dkk. (2012) Model Multimedia Interaktif Berbasis Gaya Belajar untuk Meningkatkan Penguasaan Konsep Pendahuluan Fisika Zat Padat. Jurnal Pendidikan Fisika Indonesia.8 (1): 74-8 